\title{
Magnetic Pd- and CuO-Catalyzed Regioselective Direct Arylation of Anilides
}

Key words

palladium catalysis

copper catalysis

magnetite

arylation

anilides
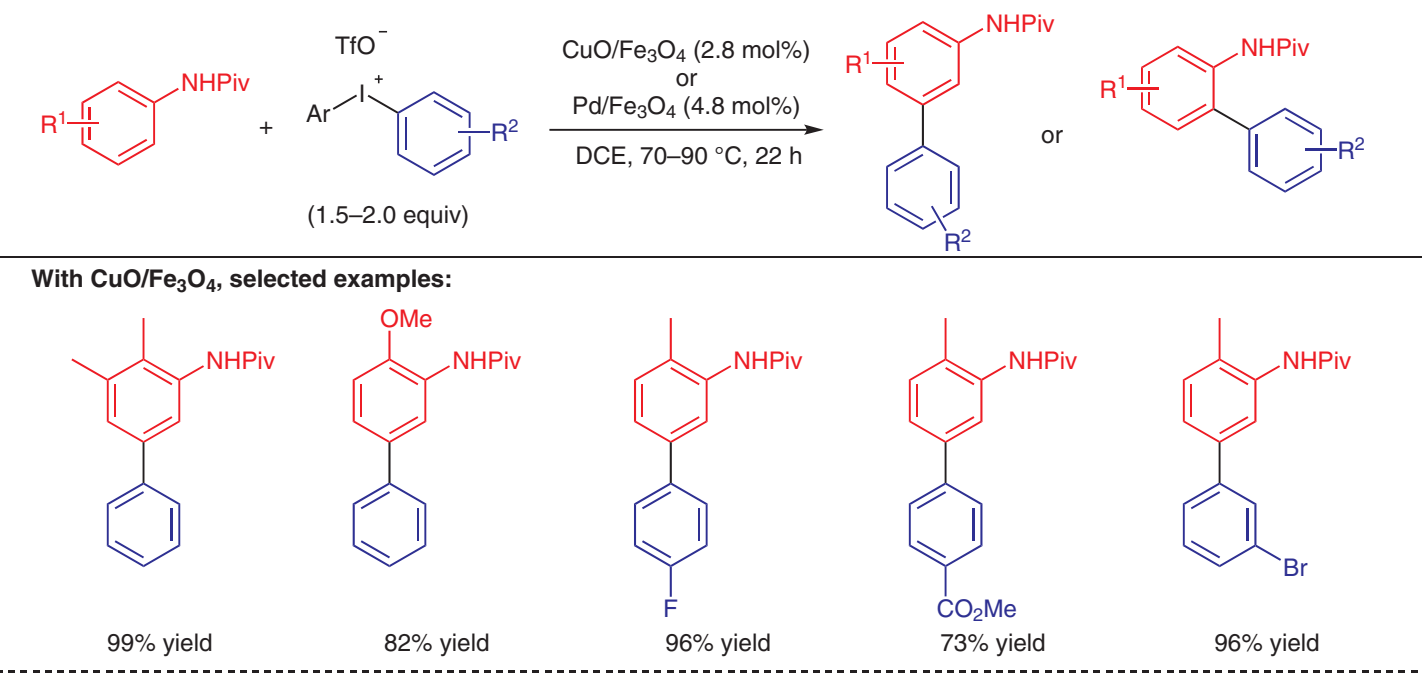

With $\mathrm{Pd} / \mathrm{Fe}_{3} \mathrm{O}_{4}$, selected examples:<smiles>Cc1ccc(-c2ccccc2)c(N=[N+]=O)c1C</smiles>

$89 \%$ yield<smiles>O=CNc1cc(F)ccc1-c1ccccc1</smiles>

$70 \%$ yield<smiles>Cc1ccc(-c2cccc(C)c2NN=N)cc1</smiles><smiles>CC(=O)Nc1c(C)cccc1-c1ccc(C(C)=O)cc1</smiles><smiles>Cc1cccc(-c2ccc(Br)cc2)c1N=N</smiles>

$78 \%$ yield $(o / m=98 / 2) \quad 65 \%$ yield $(o / m=97 / 3) \quad 77 \%$ yield $(o / m=98 / 2)$
Significance: Magnetite-supported copper oxide $\left(\mathrm{CuO} / \mathrm{Fe}_{3} \mathrm{O}_{4}\right)$ or palladium nanoparticles $(\mathrm{Pd} /$ $\mathrm{Fe}_{3} \mathrm{O}_{4}$ ) catalyzed the regioselective direct arylation of anilides with diaryliodonium triflates in 1,2-dichloroethane. $\mathrm{CuO} / \mathrm{Fe}_{3} \mathrm{O}_{4}$ exclusively afforded the meta arylation products in up to $99 \%$ yield, whereas $\mathrm{Pd} / \mathrm{Fe}_{3} \mathrm{O}_{4}$ gave ortho arylation products in up to $89 \%$ yield.
Comment: In the direct arylation of $\mathrm{N}$-(o-tolyl)pivalamide with diphenyliodonium triflate, $\mathrm{CuO} /$ $\mathrm{Fe}_{3} \mathrm{O}_{4}$ was magnetically recovered and reused four times without loss of its catalytic performance. On the other hand, the catalytic activity of $\mathrm{Pd}$ / $\mathrm{Fe}_{3} \mathrm{O}_{4}$ decreased after one recycling. Hot filtration tests and TXRF analysis indicated that catalytically active soluble species were generated in situ from $\mathrm{CuO} / \mathrm{Fe}_{3} \mathrm{O}_{4}$ and $\mathrm{Pd} / \mathrm{Fe}_{3} \mathrm{O}_{4}$ during the reaction.

SYNFACTS Contributors: Yasuhiro Uozumi, Shun Ichii 